\title{
都市雨水貯留施設の水質改善および利水効果評価式の実用化

\author{
A PRACTICAL EXPRESSION OF EFFICIENCY OF DETENTION STORAGES \\ FOR POLLUTION AND WATER SUPPLY CONTROLS
}

\author{
江 藤 剛 治* • 中西祐 啓** ・栗田秀明*** \\ By Takeharu ETOH, Masanori NAKANISHI and Hideaki KURITA
}

\begin{abstract}
First, an expression of efficiency of detention storages for water quality and supply controls, which was derived by the authors, is briefly explained. The expression contains several parameters, which represent characteristics of (1) rainfall time sequence, (2) land-use and (3) the storage-treatment system. The rainfall characteristics all over Japan are analyzed using data of AMeDAS, the automatic meteorological data acquisition system of the Japan Meteorological Agency, and, then, values of the parameters relating to the expression are summarized on the map of Japan with contours. A process of estimation of the efficiency by the proposed method is exemplified for a hypothetical and typical size of a house detention pond in the Tokyo area.

Keywords : detention storage, storage-treatment system
\end{abstract}

\section{1.はじめに}

雨水貯留の主目的は, 治水・利水, および雨水の放流 先水域の水質保全である. 加えて, 貯留池に修景機能や, 親水・レクリェーション機能をもたせる場合, さらには, このような施設に身近に接することを通じて，水管理に 対する興味と理解を深めさせるという啓蒙的な役割を期 待する場合もある (補遺 1 ). 一方これらの目的間には 貯留空間の利用形態について, 強い競合関係が存在する 場合がある(補遺 2 ).

わが国の都市雨水の貯留施設の多くは, 治水を主目的 とするものであるが, 北米やヨーロッパでは水質保全を 主目的亡するものも多い.たとえば大規模地下貯留で有 名なシカゴの TARP (Tunnel and Reservoir Plan) の 第 1 段階の目的は, シカゴの上水源であるミシガン湖の 水質保全であったことは良く知られている. 大雨時に合 流式下水道から溢流してミシガン湖に流入していた水を いったん貯留し, 降雨終了後に, 既存の処理施設に送り,

* 正会員 工博 近畿大学教授 理工学部土木工学科 ( ₹577 東大阪市小若江 3-4-1)

** 正会員 工修 (株) 大本組土木部技術開発課 (₹700 岡山市内山下 1-1-13)

*** 正会員 工博 (株) 建設技術研究所大阪支社技術第 3 部 ( 至5 541 大阪市中央区本町 1-4-7)
夜間の余剰処理能力を利用して二次処理したうえで, 途 中に湖沼等の閉鎖性水域をもたないイリノイ川・ミシ シッピー川に放流することにより, 溢流水によってミシ ガン湖に流入していた污濁負荷量を激減させた. 全面的 な分流化により同一の効果を得る場合に比べて，1/4の コストで済んだとされている.わが国でもこの方式の貯 留施設 (雨水滞水池) が計画・建設され始めている.

島璵部では，古くから貯めた雨水を利水目的に使う例 が多くみられたが, 最近では都市部でも雨水の雑用水利 用を目的とした貯留施設が作られ始めている.この場合 上水道からの給水に比べてコスト高となるので，治水を 主目的として作った雨水貯留施設の兼用が多い.ただし 啓蒙的な効果等を計量することができれば，経済性から みても意味があることを示すことができるかもしれな い.

著者らはこのような雨水貯留施設の機能の評価につい て研究を続けてきた ${ }^{1) ~ 7)}$. 基本方針として降雨量時系列 における偶発性を評価過程の中に組み入れること，でき る限り厳密に理論解析すること，かつ結果として実用に 耐え得る簡便な式を導くことを方針とした。

治水目的に対しては, 与えられた治水安全度（この場 合汇濫頻度を指標としている) を確保するに必要な, 貯 留施設規模と下流の排水施設規模 (疎通能, ポンプ容量 
なよ゙）の関係がきわめて簡単な表現で表わされることを 示した1)。これを等危険度線の式とよぶことにした（補 遺 3 ). またこれを実用化するために, 式中のパラメ一 夕一を, 降雨の確率特性, 流域の土地利用条件を代表す る流出率と到達時間, 貯留施設の水理構造を代表する貯 留施設の貯留関数の指数, 等から簡便に推定する方法を 提案した (標準等危険度線 $)^{3)}$.

水質保全を目的とする場合 (雨水滞水池)については, 貯留容量が非常に大きい. あるいは小さいなどの特別の 条件下で, 流域からの污濁負荷の流出特性, 降雨流出の 確率特性等が与えられたときの, 貯留施設容量および水 処理施設の能力に対する, 放流水域への流入負荷量の削 減率の関係を表わす式を理論解析により導(た ${ }^{4), 5)}$. 本 論文は雨水滞水池についての理論解析の結果を総合し, さらにこれらを実用化するために行った一連の研究成果 をとりまとめたものである.

まずこれまでの理論解析で設定した条件と, そのおの おのに対して得られた負荷削減率の式について簡単に紹 介する.次にこれらの式を総合し, 実流域に対するシミュ レーション結果等を参考にして修正することにより最終 的に得られた実用的な式を示した. また後述の放流負荷 削減率の式中の洗浄係数を 0 (無限小) とし, 除去率を 1 にすると，この式は利水を目的とした貯留施設の雨水 利用率の式となることを示した（以上 2. ).

式中には降雨の確率変動特性を代表するパラメーター が入っている. AMeDAS の降雨資料を用いて日本全土 に対してこれらのパラメーターの值を推定し, 等值線を 日本地図上にプロットした（以上3.).

最後に実際の計算例により，2.の結果と3. の地図 を用いて, 利水効果 (雨水利用率) を簡便に評価するこ とができることを示すとともに，その場合の注意すべき 点等を指摘した（以上 4.).

\section{2. 効率の式}

\section{（1）導出過程の要約}

以下は文献 4)～6）の要約である(補遺 4 ).

貯留・処理システムから放流水域に放流される負荷量 は，貯留施設から溢流するものと，処理施設から放流さ れるものの和である. 前者は大雨時に貯留施設が満水と なって未処理のまま溢流水とともに流出する負荷量であ り, 後者は貯留施設での沈殿および処理施設での水処理 により除去された後, 処理水中に残った負荷が放流され る分である.ここでは溢流水と放流水を合わせて放流水 (または負荷量) とよぶことにする.

評価指標としては 2 種考えられる. 1 つは年を通じて の放流負荷の総量の削減効果を問題とする場合であり, 他の 1 つは一雨ごとの放流負荷量の変動に着目し, ピー
ク值がある基準值を超える確率を，ある水準以下に押え るという場合である．本論文では前者を評価指標として いる. すなわち計画対象の貯留・処理システムが存在す る場合の年間を通じての総流出負荷量と, ない場合のそ れの比を「放流負荷削減率」(あるいは簡単に「削減率」) とよんで評価指標 $\varepsilon$ とする.

削減率を, 貯留施設容量 $z_{0}$, 単位時間当たりの処理 水量 $d$ の関数で表わす.これらの施設容量は, 次のよ うに無次元化しておく.

$$
Z_{0}=z_{0} / \bar{v}, \quad D=d \cdot \overline{t_{R}} / \bar{v}
$$

ここに, $\bar{v}$ は平均一雨流出量, $\overline{t_{R}}$ は平均流出時間間隔.

すなわち $Z_{0}$ は, 平均的にみて一雨で流出する総流量 $\bar{v}$ の何倍の貯留施設をもっているか， $D$ は一雨と次の一 雨の間に処理できる水量 $d \cdot \overline{t_{R}}$ が, 一雨流出量 $\bar{v}$ の何倍 であるかを示している。

理論式の導出には多くの仮定を必要とするがそのうち 主なものは次の 3 つである.

(1) 降雨流出量時系列は複合ポアソン過程に従うとす る. すなわち一雨と一雨の時間間隔 $t_{R}$ は指数分布に従 い, また一雨ごとの総流出量 $v$ もまた確率分布すると する. $v$ の分布も指数分布とした $(4)$, p. 282 , 右 37 行 p. 283, 左 3 行).

(2) 污濁物質の流出強度 (単位時間当たりの流出量) は, 流域に残存している負荷量と降雨の流出強度に比例 する. 比例定数を洗浄係数 $k_{c}$ とよぶことにする. また 各流出現象発生時の初期流域残存負荷量は一定であると する (補遺 5 ) ( 4), p. 283, 左 4 21 行).

(3) 貯留施設における沈殿と水処理により除去される 負荷の, 流入総負荷量に対する割合 (除去率 $k_{t}$ ) は, 貯留水量等によらず一定である (4), p. 282, 右 25〜 34 行).

他の研究者による現地観測により, 初期残存負荷量が 先行無降雨日数とともに増加すること, 除去率は貯留水 濃度や滞留時間の関数となること, 流出污濁負荷量と降 雨強度の関数関係は污濁負荷の種類により異なること, などが明らかになっている，しかし個々の流出事象にお いて，上記の仮定を採用したことによる上下のばらつき は, 年平均の削減率を計算する場合は平均化されるので, 大きな誤差要因になるとは考えられない，本研究では， これらの仮定により, 基本的なシステム特性について解 析的な検討が可能になるという利点の方を優先してい る.

残念ながら，このような仮定を採用しても一般的な条 件下で厳密に陽解を導くことはきわめて困難である（補 遺 6 ). よって次の手順で実用的な近似式を導いた。

(1) 貯留施設容量が無限小, 無限大等の条件 ${ }^{4}$, ある いは貯留施設への平均流入量と処理容量が等しい場 
合5), などの特殊な条件下で陽解を導く.

(2)これらの解を総合し, かつ, 実際の降雨流出量時 系列はポイント・プロセスではなく，ある程度降雨流出 が継続することなど, 理論解析では無視した要素も考慮 して，一般的な条件に対して使える近似式の式形を想定 する. (6), p. 217,9 行 p. 218,35 行. 式中の係数 值については未知量とし, 代表的なケースに対するシ ミュレーション結果と近似式から計算された の 2 乗和が最小となるように係数值の組を定める（6), pp. 224 226).

最終的に得られた式は次のとおりである.

$\varepsilon=k_{t}\left(1+K_{c}\right) C\left\{1-\exp \left(-Z_{0}^{\prime} / C\right)\right\} \cdot$

ここに,

$$
\begin{aligned}
& Z_{0}^{\prime}=Z_{0}-c_{z d} Z_{d}^{\prime}+D T_{r} \\
& Z_{d}^{\prime}=Z_{0}-2 \cdot \ln \left\{2-\exp \left(-Z_{0} / 2\right)\right\} \\
& C=D /\left(1+K_{c} D\right), \quad c_{z d}=\sqrt{D} \quad(D \leqq 1 \text { のとき }) \\
& C=1 /\left(1+K_{c}\right), \quad c_{z d}=1 / \sqrt{D} \quad(D>1 \text { のとき }) \\
& Z_{0}=z_{0} / \bar{v}, \quad D=d \cdot \overline{t_{R}^{\prime}} / \bar{v}, \quad T_{r}=\overline{t_{r}^{\prime}} / \overline{t_{R}^{\prime}} \\
& \bar{v}=f^{\prime} \overline{r^{\prime}} A, \quad K_{c}=\bar{v} k_{c}
\end{aligned}
$$

ここに, $\overline{t_{r}^{\prime}}, \overline{t_{R}^{\prime}}, f^{\prime}, \overline{r^{\prime}}, T_{r}$ は, 初期損失 $f_{0}$ を差し 引いた後の一雨降雨についての, 平均降雨継続時間, 平 均降雨時間間隔, 流出率, 平均一雨降雨量, 無次示平均 降雨継続時間である. $A$ は流域面積.

$k_{t}=1, K_{c}=1$ に対するモンテ・カルロシミュレーショ ン結果と式 ( 2 ) の比較例を図一1に示している. シミュ レーションとしては,このような理論模型と本質的に同
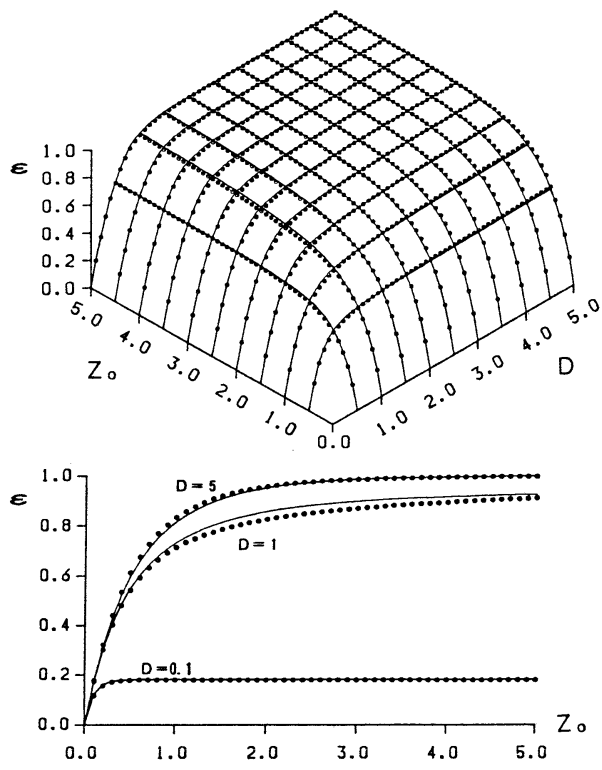

図一1 式 ( 2 ) の精度 $\left(k_{t}=1, K_{c}=1\right.$ の場合 $)$ 実線: 式 (2), 点: シミュレーション (下図は上図の $D=$ 一定に対する断面図)
等なもののほかに，実際に雨水滞水池が作られた流域で の, 現実に近い状態に対するシミュレーションも行い, 式（2）と比較した. モンテ・カルロシミュレーション に対する式（2）の相対誤差は平均約 3\% である（6）, pp. 219 224).

\section{（2）流出量時系列と降雨量時系列}

流出量時系列を, 降雨量時系列特性と流域の土地条件 に分離して表現できれば便利である．以下では都市流域 を想定する.

たとえば流出時間間隔は本質的には降雨時間間隔と同 様の概念であるが，弱い雨に対しては流出は生じないの で, 降雨時間間隔より流出時間間隔の方が大きくなる. 都市流域では, 不浸透域ではたかだか数 $\mathrm{mm}$ 以下の初 期損失 $f_{0}$ があるのみで, それ以上の雨に対しては必ず 流出が起こる。また特に大きな降雨でないかぎり, 初期 損失を除く雨量に対する流出率 $f^{\prime}$ は, 不浸透面積率と ほぼ等しい. よって各一雨降雨から初期損失分を差し引 き, $0 \mathrm{~mm}$ 以上の降雨群を新たに一雨降雨群とみなし, その平均時間間隔 $\overline{t_{R}^{\prime}}$ を求めれば, 実用的には, これが 流出時間間隔にほぼ等しいと考えられる.

また初期損失を差し引いた一雨降雨群の平均一雨雨量 $\overline{r^{\prime}}$ を求め, これに, 流域面積 $A$ と不浸透面積率（流出 率 $\left.f^{\prime}\right)$ を乗ずれば，平均一雨流出量 $\bar{v}$ が求まると考え られる。

一方平均流出継続時間については, 都市域の直接流出 においては, 初期損失後の平均降雨継続時間 $\overline{t_{r}^{\prime}}$ に集中 時間 $t_{c}$ を加えたものにほぼ等しいと考えられる。たた し都市域ではおおむね $\overline{t_{r}^{\prime}}>t_{c}$ であり, また無次元降雨 継続時間 $T_{r}$ に対する, 式 $(2)$ の削減率 $\varepsilon$ の感度は小 さいので, $\left(\overline{t_{r}^{\prime}}+t_{c}\right)$ を $\overline{t_{r}^{\prime}}$ で近似しても $\varepsilon に$ 対しては大 きな誤差は生じない.

以上より，流出時系列の特性值を，流域特性に関する もの, すなわち, (1)流域面積 $A$, (2)初期損失 $f_{0}$, (3)不 浸透面積率 $f^{\prime}$ ， および初期損失を考慮した降雨量時系 列の特性值, すなわち, (4)平均一雨雨量 $\overline{r^{\prime}}$, (5)平均降 雨時間間隔 $\overline{t_{R}^{\prime}}$, (6)平均降雨継続時間 $\overline{t_{r}^{\prime}}$, の 6 個のパラ メーターで代表し, 推定することができる.

\section{（3）利水効果の評価への適用}

洗浄係数 $k_{c}$ が無限小の上き, 流域から洗浄されて流 出する負荷量も無限小となるので, 流域残存負荷量は, 流出期間を通じて初期残存負荷量に等しく一定值とな る. 流出負荷量は, 残存負荷量と, 時々刻々の流出量に 比例すると仮定しているので（(1) 仮定(2)), 残存負荷 量が一定值であれば, 流出負荷量と流出水量は比例する. この場合流出水, すなわち貯留施設への流入水の濃度は 常に一定となる。貯留施設に貯えられる未処理水濃度も これに等しく一定值となる. ここで除去率 $k_{t}=1$ とすれ 
ば,処理施設を通過した全負荷が除去されることになる. このときの負荷削減率 $\varepsilon$ は, 流入した総負荷に対する 処理施設を通過した総負荷の比であり，濃度一定の条件 より，この值は，流入した総水量に対する処理施設を通 過した総水量の比に等しくなる. よって, $k_{c}=0, k_{t}=1$ 之置けば，式 $(2)$ は貯留施設への総流入雨水のうち, $\varepsilon(\times 100 \%)$ が処理施設を経由する水量の割合である ことを示している.このとき, 利水用の配水ポンプを処 理施設とみなすと， $\varepsilon$ が貯留施設から配水ポンプを経由 して利用可能な雨水の割合を示していることがわかる. すなわち, 式 (2) は利水目的の雨水貯留施設の効率を 示す式となる.この場合は $\varepsilon$ を雨水利用率（あるいは 利用率）とよぶことにする.

\section{（4）洗浄係数が未知の場合の負荷削減率の推定}

式（2）を実用に供するには，その地点の降雨時系列 特性の代表值, および流出率のほかに, 除去率 $k_{t}$, 洗 净係数 $k_{c}$ がわかっている必要がある.

除去率 $k_{t}$ については，施設の設計の段階で，処理方 式および負荷の種類ごとに決めれられているはずであ る.

洗浄係数を実測値から求めるには，累加流出量・累加 負荷量曲線に指数関数をあてはめ，その係数から推定す ることが可能である（補遺 5 ）。この值は，負荷の種類 と土地利用条件によって変わると考えられるので，その 標準值を求めるには, 多くの信頼性の高い実測值が必要 となる．残念ながら著者らの研究組織ではこれらの実測 資料についての蓄積がない.

これらが未知の場合には，当面，利水目的の場合と同 様に, 流入水濃度一定の条件を用いることができる. ファーストフラッシュ効果が著しく卓越するような污濁 物質を除けば，年平均レベルの評価においては，この近 似は十分許容し得るものと考えられる．このとき前節の 議論之同様に， $k_{c} \rightarrow 0$ となる. よって洗浄係数の值は わからなくても負荷削減率 $\varepsilon$ を計算することができる.

もし削減量が必要になる場合は,年間の負荷流出量(ま たは生産量）に $を$ を乗じることによって算定できる. 年間の負荷流出量については, 現在でも, 土地利用状況 と負荷の種類ごとの原単位を用いてある程度の精度で推 定することができる.

実際には $k_{c}>0$ であるが，このときファーストフラッ シュにより降雨流出初期に高濃度の污濁水が流出し, こ れを貯留・処理するので削減率はより高くなる．よって $k_{c} \rightarrow 0$ の近似により, 削減率 $\varepsilon$ は過小評価される. 逆 に必要施設容量はやや大きくなるので, この近似は安全 側となる。

\section{3. 降雨量時系列の特性量}

\section{（1）用いた資料}

a) 観測期間と地点

式（2）を使うには, 式中のパラメーターのうち, 降 雨量時系列の特性值を求めておく必要がある。これらを 各地点の降水量時系列の実測資料から計算しても良い が, 前もって日本各地について計算された值が水文地図 として準備されていれば便利である71.

資料としては 1976 1985 年の 10 年間のアメダス降水 量資料を用いた．全国 1318 地点の観測点から，冬期等 に欠測の多い観測所を除き, 778 地点の観測所を選んだ. 確率雨量等の極值統計の評価には 10 年という期間は短 かすぎるが, 本論文のように一雨降雨等の平均量を求め るには 10 年間の資料で十分であろう.

b) 欠測の処理

778 地点の観測所にも欠測があるが，この場合は欠測 中の時間は存在しなかったものとし，その前後の観測値 を続けて連続記録とした。実際の欠測は一地点の一連の 観測期間中にばらばらと生じるのではなく，一度生じる とかなり長期にわたって生じるので，このようにしても 一雨雨量の平均值等の推定誤差は小さい。 また欠測は冬 期に降雪地域に生ずることが多いが，後述のごとく，こ のような地域では冬期を適用対象期間から除外している ので，ほとんど問題は生じない.

\section{（2）計算の方法}

a) 一雨の定義と初期損失

「一雨」を定義することは困難である，現状では，用 途ごとに決めざるを得ない. 都市域の直接流出の集中時 間はたかだか 1 2 時間であるから，まず，無降雨が 3 時間以上継続したとき, 別の一雨とした. また都市の不 浸透域は，1〜4 $\mathrm{mm}$ 程度の初期損失があるとされてい $る^{8)}$. この值を $2 \mathrm{~mm}$ に固定した. よって当初作成した すべての一雨から $2 \mathrm{~mm}$ を差し引き， $0 \mathrm{~mm}$ 以上の值と なったものを新たに一雨とした。

これより平均一雨雨量, 平均降雨時間間隔，平均降雨 継続時間を求めた。なお降雨時間間隔は一雨の降り始め から, 次の一雨の降り始めまでの時間であり, 前の一雨 の継続時間を含んでいる.

b) 積雪期間の除外

積雪が続く場合は, 雨水貯留施設は全く機能しないか, または降雨流出に対する機能のしかたとは全く異なった 使い方になろう。よって式（2）で表わされる水質保全, 利水機能の評価においては, 積雪時は除外して考えねば ならない。

わが国においては冬期に積雪が多い地域とそれ以外の 地域はかなり明瞭に分離できる. 分離の方法について検 
討した結果，次の方法による分離が直感的に予想される 結果とも良く一致することがわかった.

平年值降雪開始日から同降雪終了日までを降雪期間と し，その日数が 100 日以上の地域を積雪地域とした. 平 年值降雪開始日・終了日の統計は各気象台・測候所単位 で得ることができる。降雪期間が 100 日程度の地点にお いては，おおむね平年值降雪開始は 12 月中旬，終了は 3 月中旬である. よってこれらの地点については 12 月 から 3 月までを降雪期間として除外し，4１1月の資料 で式（2）中の統計值を計算した.

それ以外の地域についても 12〜3 月の冬期と, $4 \sim 11$ 月では気象特性も大きく変わるし, 貯留施設の使い方も 変わる可能性がある. 利用の可能性としては 4 11 月の 方がはるかに高い。一方年間の総負荷削減率を計算する には，通年の統計值を基礎とする必要がある.よってこ れらの地域については，通年で計算したものと，4 11 月の值のみで計算したものの 2 種を用意した.

c) 等高線の作成

778 地点の観測所を用いても地方によってはかなりま ばらな情報となる.よって以下の手法で求めたメッシュ 情報から等高線を描いた7).

経緯 6 分ごとのメッシュとする.メッシュ幅は緯度方 向で約 $11 \mathrm{~km}$ 程度である. 各メッシュ点を中心に半径 $50 \mathrm{~km}$ の円を描き，その中にある観測点の值を平滑化す る. 平滑化においては当該メッシュ点に近いものほよ゙大 きな重みがかかるように, 観測点までの距離 $(\mathrm{km}$ 単位)
の 2 乗に逆比例する重みをかけて重みつき平均を求め た.このメッシュ情報から等高線を描いた。

\section{(3) 結果}

結果を図一2〜4に示す.ただし初期損失等を考慮し ているので，そのまま平均一雨雨量等を求めた結果とは 若干異なることに注意しておく. 特に, 平均降雨時間間 隔は長くなっている.これらの図は実用上便利であると いうことのほかに, わが国の降雨量特性の全般的傾向に ついて，興味深い性質を示している。それらについて要 約する.

(1) 平均降雨継続時間については地域性はほとんどみ られず，いずれの地域においても 5〜9 時間で平均 6〜7 時間程度である（図一 4$)$.

(2) 平均降雨時間間隔は，4〜11月について 70〜140 時間で平均 100 時間 (4日) 程度である。ただし地域性 があり，北に行くほど長くなる(図一3).

(3) 平均一雨雨量は多雨域では $30 \mathrm{~mm}$ 以上, 少ない ところでは $10 \mathrm{~mm}$ 以下と非常に大きな差がある.これ は同一地域の中でも大きく変わっている（図-2）.

(4) 少降雪地域（太平洋南岸地域）では，4１1月の 資料と通年の資料を用いたものには大きな差はない。た だし 4〜11 月の方が降雨回数, 一雨雨量ともに大きいの で, 通年の方が平均降雨時間間隔はやや大きく, 平均降 雨継続時間は少し小さい（図一2４）.

(1)〜(3)より次のように解釈できる.

4〜11月においては，北に行くほど降雨頻度が小さく

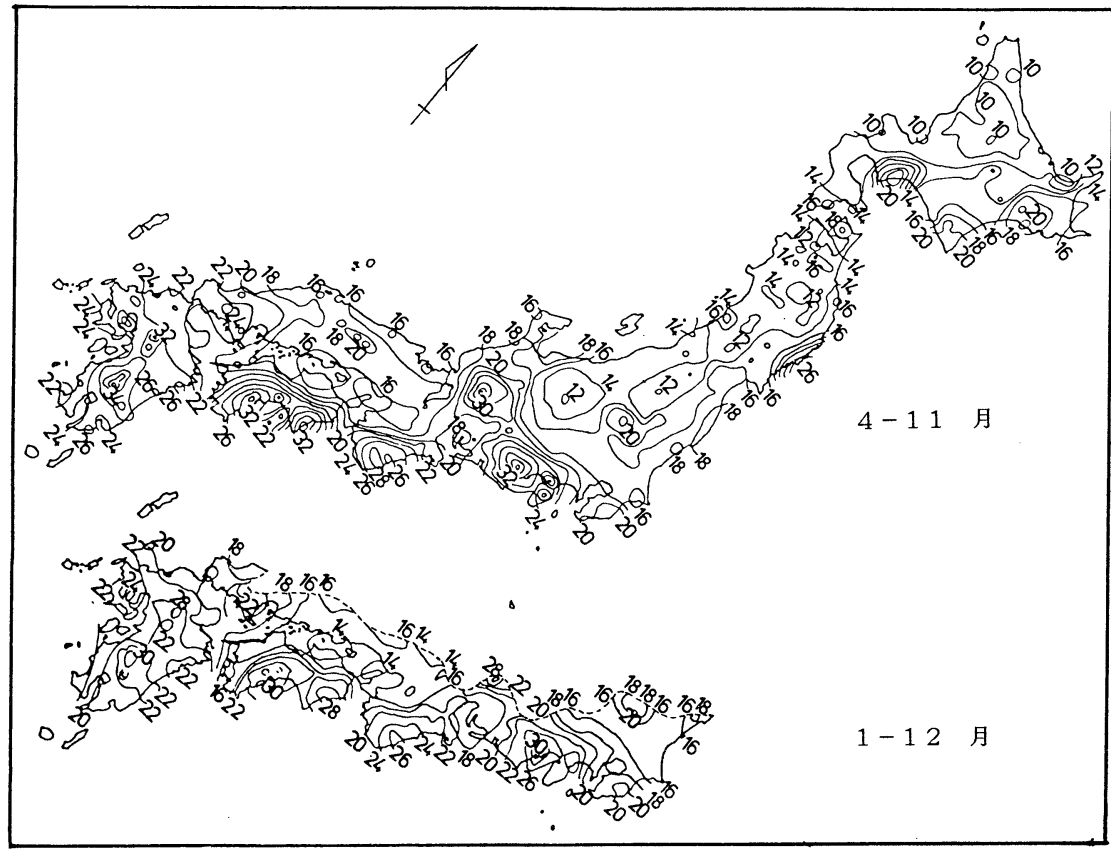

図一2 平均一雨雨量 $\bar{r}$ 


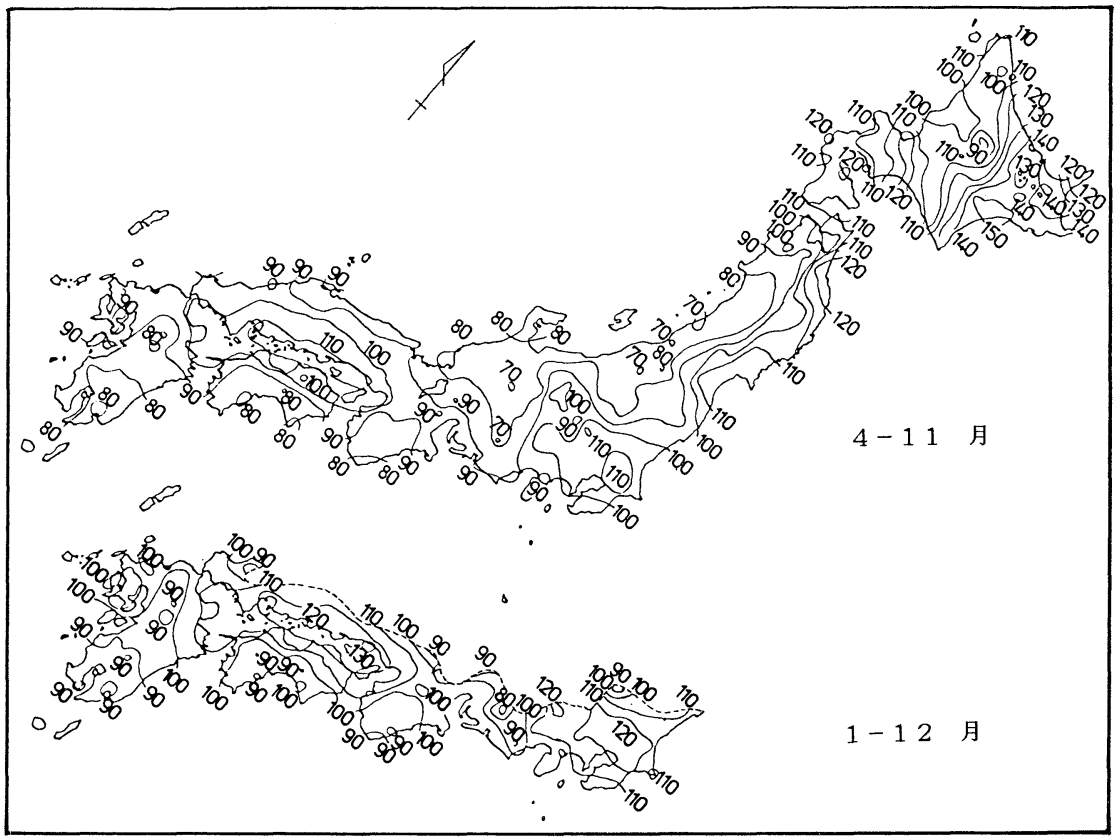

図一3 平均降雨時間間隔 $\overline{\boldsymbol{t}_{R}^{\prime}}$

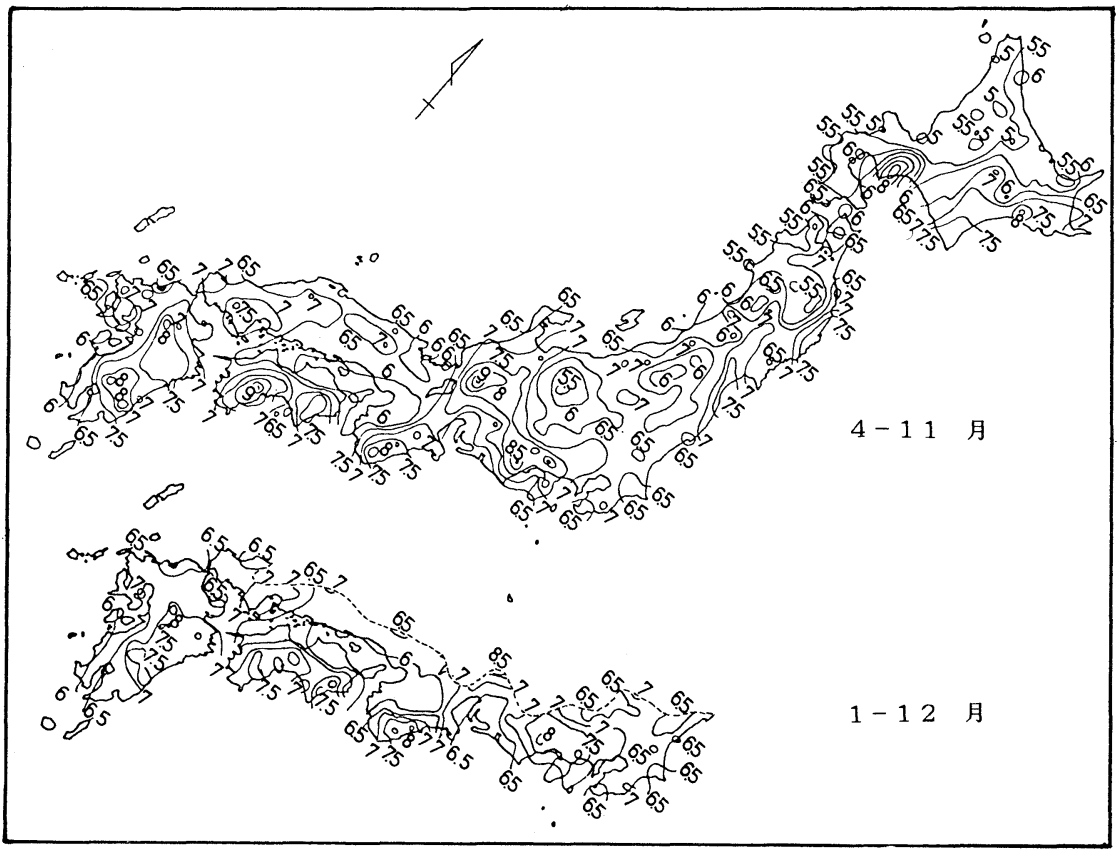

図-4 平均降雨継続時間 $\overline{\boldsymbol{t}_{r}^{\prime}}$

なる (2)). たとえば九州で 3〜4 日に一度, 北海道では 4〜6 日に一度程度である. 平均 4 日強に一度程度であ る. 偏西風带の風速に 4 5 日の周期成分が含まれてい ることはよく知られている. 大阪の日降水量時系列でも 同程度の周期成分がみられることは著者らの解析でも明 らかにされている9 . このように各降雨をもたらす不安
定な気象状態の継続性は日本国内では地域によらずほぼ 一定である. またその主たる要因は北極を中心とする偏 西風波動であろう。

日本上空の気象擾乱の移動速度を $40 \mathrm{~km} / \mathrm{h}$ (1 日に約 $1000 \mathrm{~km}$ 東進）程度とすれば，これに5〜9時間の継続 時間を乗ずると (1))，その空間規模は 200～360 km と 
なり，直感的に予想される低気圧等の空間規模に一致す る.

一雨雨量については地域性のほかに地形に大きく依存 する (3)). 平均的には $10 \mathrm{~mm}$ 余りの比較的小さい值と なる北海道においても，東南に開けた半島部では 20 $\mathrm{mm}$ を越える地域もある.

\section{4. 利 用 例}

\section{（1）条件}

図一2 4 と式（2）の利用例を示す. 東京で個人の 家に雑用水利用を目的として雨水貯留槽を作る場合を考 える (表一1 参照).

宅地面積を $A=300 \mathrm{~m}^{2}$ とし， $f^{\prime}=60 \%$ が屋根・駐車 場等の不浸透面とする. 降雨特性については図一 2 より, $\overline{r^{\prime}}=17 \mathrm{~mm}, \overline{t_{R}^{\prime}}=110 \mathrm{~h}=4.58$ days, $\overline{t_{r}^{\prime}}=7 \mathrm{~h}$.

施設規模については, 貯留容量 $z_{0}=5 \mathrm{~m}^{3}$, 雑用水の 使用水量 $d=0.05 \mathrm{~m}^{3} / \mathrm{h}=1.2 \mathrm{~m}^{3} /$ day とすると, 平均一 雨流出量 $\bar{v}=3.06 \mathrm{~m}^{3}$. また 1 日当たりの平均流出量は $\bar{v} / \overline{t_{R}^{\prime}}=0.668 \mathrm{~m}^{3} /$ day.

式 (1) より, 無次元使用水量 $D=1.80$, 無次元貯 留容量 $Z_{0}=1.63$, 無次元流出継続時間 $T_{r}=0.064$ であ る.これらの值により, 平均一雨流出量に対して何倍く らいの使用水量, 貯留施設を想定しているかがわかり, 概略のシステム特性を予想することができる.

\section{(2) 機能 評価}

以上より式 $(2)$ を用いて雨水利用率を計算すると, $\varepsilon=0.695$ ，すなわち約 $70 \%$ となる.

平均雨水利用量を $q_{r}$ とすると $q_{r}=\bar{v} / \overline{t_{R}^{\prime}} \cdot \varepsilon=0.465$ $\mathrm{m}^{3} / \mathrm{day}$. 平均不足水量と上水道加らの平均供給水量は

\section{表一1 東京のある家庭の雨水利用施設計画のまとめ}

\begin{tabular}{|c|c|c|c|}
\hline \multicolumn{2}{|c|}{ 項 } & 値（単位） & 備 \\
\hline $\begin{array}{l}\text { 土地利用 } \\
\text { 性 }\end{array}$ & $\begin{array}{ccc}\text { 流 } & \text { 域 } & \text { 面 } \\
\text { 流 } & \text { 出 } & \text { 率 } f^{\prime} \\
\text { 初 } & \text { 期 損 } & \text { 失 } f_{0}\end{array}$ & $\begin{array}{l}300 \mathrm{~m}^{2} \\
0.6 \\
2 \mathrm{~mm}\end{array}$ & $\begin{array}{l}\text { 不浸透面積率 } \\
\text { 都市域では固定 }\end{array}$ \\
\hline 降雨特性 & $\begin{array}{l}\text { 一 雨 雨 量 } \overline{r^{\prime}} \\
\text { 降雨時間間隔 } \overline{t_{R}{ }^{\prime}} \\
\text { 降雨継続時間 } \overline{t_{r}{ }^{\prime}}\end{array}$ & $\begin{array}{l}17 \mathrm{~mm} \\
110 \mathrm{~h} \\
7 \mathrm{~h}\end{array}$ & すべて年平均(図より) \\
\hline & 一雨流出量 $\bar{v}$ & $3.06 \mathrm{~m}^{3}$ & $1 / 1000 \cdot f^{\prime} r^{\prime} A$ \\
\hline 施設規模 & $\begin{array}{l}\text { 使 用 水 量 } d \\
\text { 眝 留 容 量 } z_{0}\end{array}$ & $\begin{array}{l}1.2 \mathrm{~m}^{3} / \mathrm{day} \\
5 \mathrm{~m}^{3}\end{array}$ & 補給用水道管容量も同 \\
\hline $\begin{array}{l}\text { 主要な無 } \\
\text { 次 元 疃 }\end{array}$ & $\begin{array}{l}\text { 利 用 水 量 } D \\
\text { 眝 留 容 量 } Z_{0} \\
\text { 降雨継続時間 } T_{r}\end{array}$ & $\begin{array}{l}1.80 \\
1.63 \\
0.064\end{array}$ & 降雨時間比 \\
\hline 機能評価 & $\begin{array}{l}\text { 雨水利用率 } \varepsilon \\
\text { 雨水依存率 } \delta \\
\text { 雨水利用量 } q_{r} \\
\text { 不足 水 量 } q_{s}\end{array}$ & $\begin{array}{l}0.696 \\
0.388 \\
0.465 \mathrm{~m}^{3} / \text { day } \\
0.735 \mathrm{~m}^{3} / \text { day }\end{array}$ & $\begin{array}{l}\text { 式 }(2) \\
1-\text { 上水道依存率 } \\
\bar{v} \overline{t_{r}{ }^{\prime}} \varepsilon \\
\text { 上水道補給量 }\end{array}$ \\
\hline & 要 検 討 & 円 & \\
\hline
\end{tabular}

等しい.これは使用水量から平均雨水利用量を差し引く ことによって計算できる.これを $q_{s}$ と書くと, $q_{s}=d$ $-q_{r}=0.735 \mathrm{~m}^{3} /$ day.

雨水依存率 $\delta$ は, $\delta=\left(\bar{v} / \overline{t_{R}^{\prime}} \cdot \varepsilon\right) / d=0.388$, すなわち $40 \%$ 弱となる.これを 1 から引くと上水道依存率となっ て $61.3 \%$.

上水道による補給については, 雨水貯留タンクが空に なった時点で全面的に上水道に依存するのが最も効率的 である. $d, z_{0}$ 等が決められた条件下で, 雨水貯留夕ン クの空容量を最大にしておくことが, 最大限に雨水を捕 捉することになるからである，よって雑用水に対する上 水道の補給用パイプの能力は, 使用水量 $d$ に等しく 1.2 $\mathrm{m}^{3} /$ day でなければならない。上水道による補給期間は 上水道依存率に等しい.

以上の結果を表一1 にまとめて示している.このシス テムにより流出した雨水の約 $70 \%$ を利用することがで き(雨水利用率 $\varepsilon$ ), 使用水量の約 $40 \%$ を雨水により補 給することができる(雨水依存率 $\delta$ ) (補遺 7 参照).

施設規模 $d, z_{0}$ を大きくすると利用率 $\varepsilon$ は 1 に近つ く. しかし利用可能な雨水の量 $\bar{v} / \overline{t_{R}^{\prime}}$ は一定で, 雨水依 存率 $\delta$ は小さくなって雨水利用のメリットは小さくな る。一方，施設建設費は無為に大きくなる．これより， 適正な施設規模も決まるはずである．効果については式 （2）に基づく上記の評価法が有効に使える.あとは費 用に関する検討が必要となる.

\section{（） その他の利用法}

式（2）はもともと雨水滞水池の効率の式である. そ の計算例は文献 6$)$ に示している.

また式（2）に基づいて，雨水滞水池や利水目的の雨 水貯留施設の設計指針や設計例の改善点を明確にするこ とができる。いずれについても論拠や一般性にやや欠け る部分がある，全般的にみて貯留容量がやや過少，単位 時間当たりの水処理能力がやや過大である, などの傾向 がみられるようである.

\section{5. 結 論}

水質保全および利水を目的とする雨水貯留施設の効率 の理論とその応用について著者らが行ってきた研究を取 りまとめた。結果は以下のとおりである.

（1）水質保全の場合の効率は, 貯留処理システムか ら放流される全負荷の削減率で, 利水目的の場合は, 流 出雨水の利用率で定義する. 両者はともに式（2）で表 わされる.

(2) 当面やや粗い近似として, 式中の洗浄係数 $k_{c}$ $=0$ と置いてよい.

（３）このとき,式（２）を使うに必要なパラメーター は, 貯留 - 処理施設の除去率, 流域面積, 不浸透面積率, 
不浸透面の初期損失を考慮したうえでの, 平均一雨雨量, 平均降雨時間間隔, 平均降雨継続時間の 6 種である.

（４）これらのうち降水量時系列の特性值について, アメダスを用いて日本全国での值を計算し，それを等高 線表示して一種の水文地図として表示した。またそこか ら読み取れる日本の降雨特性について考察した。

（５）それらの利用例を示した。

\section{補 遺 1}

雨水貯留に関してはすでに多くの実績があり, 成書で も取り上げられているので，一般的な説明は省略し，こ れらの書名を上げる ${ }^{10) \sim 13) .}$

\section{補 遺 2}

たかだか 1 数年に 1 度の大雨のみを対象とし，常時 の降雨流出はできる限り入れないようにして，ピーク カットのみを行う治水目的の貯留空間の利用亡，中小を 含むほとんどすべての雨を対象とし，全量カットにより 流出初期からの雨水をできる限り捕捉しようとする水質 改善，および利水目的の利用では，おのずから競合する. これらの競合関係の調整については文献 14)，15）等で 議論している.

\section{補 遺 3}

これまでにも，ある治水安全度に対する必要貯留施設 容量の式を導こうとした研究成果がいくつかある．しか しながら，これらはいずれも降雨（あるいは流出）波形 を 1 つに固定して，それに対して必要容量を計算したも のである.

著者らの解析では，降雨流出の継続時間，そのピーク 值ともに指数分布に従い，それらの組合せにより無数の ハイエトグラフ (ハイドログラフ) のパターンが存在す るという条件に基づいて，汇濫確率の式を直接導いた。

\section{補 遺 4}

文献 4) 6) を要約しているので, 議論の詳細につい ては割愛している．本論文内で説明の不十分な点につい ては必要に応じて元の論文が参照できるように，文末に 参考文献のページ，行を（4)，p.1，左 2〜5行）のよ うな形で示した。

\section{補 遺 5}

洗浄係数を求めるには次の式を使う.

$$
w=w_{p o}\left\{1-\exp \left(-k_{c} v\right)\right\}
$$

ここに, $w$ は一雨当たりの流出負荷量である. $w_{p o}$ は降 雨初期の流域残存負荷量で, 式の精度と導出の簡便さを 勘案して，降雨によらず一定としている.
ある流域に対して，いくつかの降雨流出について $w$ と $v$ の実測值の組があれば，最小二乗法等により，こ れらに式（3）を当てはめることにより定数 $w_{p o}$ と $k_{c}$ が求まる.

\section{補 遺 6}

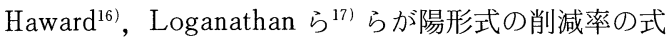
を与えているが, 解析の前提条件なざの吟味について著 者らの扱いの方が厳密である，その結果として式の簡便 さは同程度であるが精度は式（2）の方がはるかに高 $\left(^{6)}\right.$.

\section{補 遺 7}

雨水利用率 $\varepsilon$ は, 流出雨水のうち何\% が使えるかを 示すものである. 使用水量 $d$ のうち何％を雨水でまか なえるか（雨水依存率 $\delta)$ を表わすものではないことを 注意しておく. 参考文献 7）中の，この部分の説明には この誤解が含まれていた．また同文献の図にも一部不備 があった。

謝辞：図の作成等については元・近畿大学水工学 研究室の学生, 池田 (昭和 62 年大学院修士修了), 大脇 平松 (昭和 63 年卒業), 松木 ・平野 (平成元年卒業) 各 氏の協力を得た．記して謝意を表する．

研究費として, 昭和 62 年〜平成元年度文部省科学研 究費重点領域研究 (1): 京都大学 高棹教授代表（課題 番号 62601020，63601021，01601022)，同東京大学 市 川助教授代表 (課題番号 62601012,63601011, 01601011), および昭和 62 昭和 63 年度近畿大学研究助成金: 江藤 代表（課題番号 KK 03〜04），の補助を受けた。記して 謝意を表する。

\section{参 考 文 献}

1）江藤剛治・室田 明：一雨降雨の 1 確率模型，土木学会 論文集, No. 345, pp. 101 109, 1984.

2）江藤剛治・室田 明：単一貯留施設による治水の安全度 に関する理論的研究，土木学会論文集，No. 351，pp. 163 $\sim 172,1984$.

3）室田 明・江藤剛治・中西祐啓：標準等危険度線による 都市河川の治水安全度評価，土木学会論文集，No. 369/ III-5, pp. 155 164, 1986.

4）江藤剛治・栗田秀明：貯留施設を持つ水処理系による雨 天時污濁負荷削減効果の理論, 土木学会論文集, No. 375/ II-6, pp. 281 289, 1986.

5）江藤剛治・栗田秀明：流入量が処理水量と等しい場合の 雨水滞水池の効果についての近似理論, 土木学会論文集, No. 381/ II-7, pp. 231 234, 1987.

6）栗田秀明・金川正晴・田村 譲：雨水滞水池の効果に関 する理論の実用化，衛生工学研究論文集，第 23 号, 
pp. 215 226, 1987.

7）加納祐啓・江藤剛治：貯留施設の機能評価のための水文 地図とその利用例，第 33 回水理講演会論文集，pp. 181 〜 186, 1989.

8）渡辺政広・豊国永次: 都市域の流出解析（2)一流域特性 のモデル化と流出解析一, 自然災害科学, Vol. 8, No. 3, 1989.

9）江藤剛治・西村克巳：MPP モデルによる日降水量時系 列の解析, 土木学会論文報告集, No. 342, pp. 171 178, 1984.

10）日本下水道協会：合流式下水道越流水対策と暫定指針, 1982 年版.

11）熊谷純一郎・原田幸雄：雨水の貯留施設の計画と設計, 鹿島出版会, 1986 .

12）虫明功臣 - 石崎勝義ほか：水環境の保全と再生, 山海堂,
1987.

13）市川 新・マキシモヴィッチ編：都市域の雨水流出とそ の抑制, 鹿島出版会, 1988 .

14）江藤剛治：雨水貯留施設の治水 - 利水 - 水環境機能, 水 工学シリーズ, 87-A-3, 土木学会水理委員会, 1987.

15）江藤剛治：地下空間の複合利用について, 地下空間利用 に関するシンポジウム 1989.

16) Howard, C.D.D. : Theory of storage and treatment plant overflows, J. of Enviromental Engineering Div., Proc., ASCE, Vol. 102, No. EE 4, pp. 709 722, 1976.

17) Loganathan, V. G., Delleur, J.W. and Segarra : Planning detention storage for storm-water management, J. of Water Resour. Planning and Management Div, Proc., ASCE, Vol.111, No. WRPM 4, pp. 382 398, 1985.

(1990.1.16 • 受付) 